\title{
Hizbollahs irakiske profil?
}

Hizbollah har siden den israelske tilbagetrakning fra Sydlibanon i maj 2000 mistet sin umiddelbare raison d' être. Uden den israelske fjende i Libanon er bevægelsen kastet ud i en identitetskrise. Bevægelsen står splittet mellem på den ene side en pragmatisk integration i libanesisk politik samtidig med, at man på den anden side også ønsker at opretholde imaget som en kæmpende milits. Irak-krigen kan i den forbindelse vise sig nyttig som et led i Hizbollahs profilering.

Af Søren Hove, forskningsassistent ved Center for Mellemøst-studier, Syddansk Universitet. og redaktør i Mellemøstinformation.

DEN LIBANESISKe MILITS Hizbollah tager i disse dage sit image op til genovervejelse. Mens den irakiske shiamuslimske rebel, Moqtada al-Sadr, de seneste måneder har kæmpet mod de amerikanske tropper omkring den hellige Imam Ali Moske i Najaf, har Hizbollah-bevægelsen i Libanon benyttet enhver lejlighed til at rette verbale angreb mod den amerikanske tilstedeværelse i Irak.

I en større sympatidemonstration i Beirut i maj måned, som Hizbollah havde arrangeret til støtte for sine irakiske shiamuslimske brødre i Karbala og Najaf, tordnede Hizbollahs leder Hassan Nasrallah mod den amerikanske tilstedeværelse i Irak: "Kampen er fælles. Fjenden er fælles. Vi står over for én lejr, en amerikanskisraelsk lejr ... Ved at angribe de shiamus- limske helligdomme i Irak, angriber USA alle verdens shiamuslimer!" 'Den antiamerikanske tone er ikke et nyt eller usædvanligt tema i Hizbollahs retorik, men at Nasrallah fokuserer på situationen i Irak frem for det hjemlige Libanon, kan tolkes som et tegn på, at Hizbollahs profil i disse dages æendres.

I Libanon har Hizbollah siden den israelske tilbagetrakning i maj 2000 mistet sin umiddelbare eksistensberettigelse. Uden den israelske tilstedeværelse i Sydlibanon er bevægelsen blevet kastet ud i en identitetskrise. Hvilken rolle skal Hizbollah spille i fremtiden? Profilen må korrigeres, men en sådan ændring er ikke uden problemer. Bevægelsen står splittet mellem en pragmatisk integration i libanesisk politik samtidig med, at man også 
ønsker at opretholde imaget som en kæmpende milits, der ikke går på kompromis med den panislamiske ideologi.

\section{Panislamisme og nationalt engagement}

Hizbollah har fra sin fødsel i I985 under den libanesiske borgerkrig været en hybrid af modsatrettede tendenser. På den ene side er bevægelsen både ideologisk og aktivistisk forbundet med det iranske præstestyre. Ayatollah Khomeinis tanker om at sprede den islamiske revolution fra Iran til andre lande med shiamuslimske befolkninger i Mellemøsten har sat sit tydelige præg på Hizbollahs grundlæggende manifest "Det åbne brev til Verdens undertrykte” (1985), der også eksplicit henviser til Khomeini som bevægelsens ideologiske fader. ${ }^{2}$

Hizbollahs kompromisløse og radikale ideologi har desuden været bakket op af finansiel støtte og militær træning fra iransk side, som muliggjorde Hizbollahs mange aktioner under borgerkrigen. Kidnapninger af vestlige journalister, flykapringer og selvmordangreb på blant annet den amerikanske ambassade og de amerikanske marinesoldaters kaserne i Beirut i I980' erne positionerede bevægelsen blandt de mest yderligtgående islamistiske terrorister i Mellemøsten.

På den anden side er Hizbollah trods den overordnede panislamiske ideologi også forankret i det libanesiske samfund. Militsen består hovedsagelig af libanesiske shiamuslimer, der bor i Bekaa-dalen, Beiruts forstæder og det sydlige Libanon. Selvom Ayatollah Khomeini i I980' erne var og givetvis stadig er et forbillede for disse shiamuslimer, er de dog først og fremmest optaget af de problemer, som de er konfronteret med i Libanon: Det konfes- sionelle systems mangler i Libanon, den israelske fjende i Sydlibanon, de dårlige sociale forhold for shiamuslimer og så videre. På den front har Hizbollah kæmpet for bedre vilkår for shiamuslimerne $\mathrm{i}$ Libanon, hvilket blant annet er kommet til udtryk i det omfattende sociale arbejde, som bevægelsen har lagt for dagen i Beirut og Sydlibanon. Sammen med Hizbollahs aktive bekæmpelse af den israelske tilstedeværelse i Sydlibanon gennem I990' erne har den storstilede finansiering af hospitaler, sanitet, skoler og gennemopbygning af krigshærgede kvarterer givet bevæelsen stor social opbakning - ikke blot fra shiamuslimer, men fra brede dele af det libanesiske samfund. ${ }^{3}$

\section{Den sejrende milits}

Med de mange effektive aktioner mod israelske soldater har Hizbollah vundet anerkendelse i store dele af den arabiske verden. Da den libanesiske borgerkrig blev afsluttet i i989, stod Hizbollah tilbage som den eneste libanesiske milits, der aktivt vedblev med at bekæmpe den israelske besættelse af Sydlibanon.

Selvom konflikten i sin kerne var en national konflikt koncentreret omkring den ti kilometer brede sikkerhedszone i Libanon, blev kampen fortolket af både Hizbollah og andre arabiske lande som et symbol på den overordnede kamp mod Israel og Vesten. I den sammenhæeng kunne Hizbollah med sin aktive modstand profilere sig som en sjædden arabisk succeshistorie, der vidnede om kompromisløshed og modig kamp mod Israel. ${ }^{4}$

Hizbollahs image som en kæmpende milits nåede et klimaks i maj 2000, da Israel besluttede at trække sig tilbage fra sikkerhedszonen som følge af de mange 
Hizbollah-aktioner gennem I990' erne. Ikke blot i Libanon, men i hele den arabiske verden, blev Hizbollah udråbt som sejrsherre. Aldrig før var det lykkedes at få den israelske hær til at trække sig tilbage.

Sejrens symbolik er kun yderligere blevet forstærket i januar i år, hvor Hizbollah og Israel via tysk mægling har udvekslet

\section{mom \\ Hizbollahs dobbelte image som både libanesisk parti og panislamsk milits synger på sidste vers.

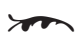

fanger. Ikke blot har Israel gennem udvekslingen indirekte anerkendt Hizbollah som forhandlingspartner, men Hizbollah har også i høj grad kunnet diktere udvekslingens præmisser.

I bytte for de jordiske rester af tre døde israelske soldater og en kidnappet israelsk forretningsmand, har Hizbollah fået 3I levende, tilfangetagne militssoldater hjem til Beirut, samtidig med at Israel også har måttet løslade 400 palæstinensiske fanger på Vestbredden og Gaza. I såvel Beirut og på Vestbredden er Hizbollah og Hassan Nasrallah ved flere lejligheder i februar blevet hyldet for sine sejre.

\section{Hizbollahs dilemma}

Men trods den israelske tilbagetrakning i 2000 og den nylige fangeudveksling står Hizbollah i dag med et tiltagende identitetsproblem. Jo flere militære og strategiske sejre bevægelsen høster som modstandsbevægelse, jo sværere bliver det at opretholde billedet af den aktivt kæmpende milits. Der er snart ikke flere fjender at bekæmpe.
Den israelske besættelsesmagt i Sydlibanon er vak. Tilbage er kun spørgsmålet om nogle få minimale områder omkring de såkaldte Shebaa Farms, der ikke har nogen større strategisk betydning. Det er ikke utænkeligt, at Israel også her trakker sig tilbage. Selvom Hizbollah, med indirekte støtte fra Syrien og Iran, per automatik forsøger at holde liv i kampen mod Israel i området omkring Shebaa Farms, er det tydeligt, at bevægelsens libanesiske relevans i forhold til den aktive kamp mod Israel er minimeret. ${ }^{5}$

Hizbollah må derfor i stigende grad bevise sin relevans over for det libanesiske samfund på andre måder. Bevægelsens nationale forankring i Libanon er dog allerede startet i første del af I990' erne, da Hizbollah i 1992 blev et politisk parti i Libanon med tolv medlemmer i det libanesiske parlament. De revolutionære tendenser og det panislamiske slogan om at "sprede den islamiske revolution" er efterhånden med årerne blevet nedtonet til fordel for et mere moderat image, der appellerer bredere til mange libanesere. Hizbollah er i denne forståelse ikke Irans forlængede arm i Libanon, men et libanesisk parti, der indgår i dagligt politisk samarbejde med parlamentets andre partier.

Dette billede af et nationalforankret politisk parti har Hizbollah gennem I990' erne kunnet kombinere med et image som en kompromisløs modstandsbevægelse, så længe man sideløbende bekæmpede Israel i Sydlibanon. Man har på den måde fået det bedste af begge verdener - dels har bevægelsen fået en bred vadgeropbakning i Libanon som et moderat libanesisk parti, dels har man på grunn av 
modstandskampen kunnet score ideologiske point i både Libanon og udlandet.

\section{Fornyet initiativ?}

Men Hizbollahs dobbelte image som både libanesisk parti og panislamisk milits synger på sidste vers. Militsens dage i Libanon er uigenkaldeligt talte, hvis også Shebaa Farms opgives af Israel. I det lys bliver Hassan Nasrallahs fokusering på situationen i Irak kendetegnende for den nuværende situation. Hizbollah ønsker tydeligvis ikke at gøre op med sit dobbelte image. Hvis Libanon er befriet, må man finde sit momentum andre steder.

Amerikanske efterretningskilder har påvist at bevæelsen endda har sendt et specialteam på Ioo mand til Basra for at gøre sig gaddende - dog uden at deltage i kampe mod amerikanske tropper. Hizbollah indgår på den måde $\mathrm{i}$ den store mobiliseringsproces af de irakiske shiamuslimer, der udgør op mod 60\% af befolkningen i Irak. Ved at indtage en mere kompromisløs og hårdere linie end for eksempel den irakiske shia-leder Ali al-Sistani forsøger Hizbollah at samle opbakning blandt de shiamuslimske masser i Irak og lægge sig i kølvandet på den stadig mere populære Moqtada al-Sadr. ${ }^{6}$

Vigtigere er dog, at den bombastiske retorik angående Irak giver Hizbollah en mulighed for at genetablere det blegnede image som aktivistisk modstandsbevægelse. Her kan de gamle paroler fra det besatte Sydlibanon stadig bruges - og det uden at bevægelsen nødvendigvis behøver at følge sine ord op med handlinger. De libanesiske shiamuslimer befinder sig så langt fra Irak, at de har ringe mulighed for at kontrollere Hizbollahs reelle aktiviteter på stedet. Man kan derfor argumentere for, at Hizbollah i højere grad udnytter situationen i Irak til at promovere sig selv. En taktik Hizbollah også har brugt i forbindelse med den palæstinensiske intifada, hvor det heller ikke har skortet på sympatierklæringer og hårde anti-israelske slogans, men Hizbollah mangler stadig at sæte handling bag ordene.

Med en retorik, der tilskynder til modstand mod de amerikanske styrker i Irak, prover Hizbollah at opretholde billedet af en kampklar og kompromisløs organisation. En retorik, som dækkker over det faktum, at Hizbollahs egentlige kamp i Libanon har mistet sin raison d'être i kraft af den israelske tilbagetrækning. På kort sigt kan bevægelsen måske hente sin legitimitet fra situationen i Irak, men i det lange løb må Hizbollah sandsynligvis indstille sig på at integrere sig fuldt i en libanesisk parlamentarisk kontekst og opgive imaget som kæmpende panislamisk milits.

\section{$\cdot f \cdot$}

I BBC: "Shia outrage over shrine attacks", BBC-news 2004/05/I9. For tidligere anti-amerikansk retorik se endvidere Blanford, Nicholas: "Hezbollah warns Bush: We will fight back", The Times, 28.07.2003.

2 Brevet findes i Norton, A. R. «Amal and the Shia-struggle for the Soul of Lebanon», (University of Texas Press, Austin, 1987).

3 Udførligt dokumenteret i bl.a. Saad-Ghorayeb, Amal: «Hizbu' llah. Politics and religion», (Pluto press, London, 2002) og i Harik, Judith Palmer: «Hezbollah. The Chang ing Face of Terrorism» (I.B: Tauris, London, 2004).

4 International Crisis group: "Old Games, New Rules: Conflict on the Israel-Lebanon Border", ICG Middle East Report no 7, I8th November 2002; Amman/Brussels.

5 Byman, Daniel: “Should Hezbollah be next?", Foreign Affairs, vol. 82, Issue 6, nov/dec 2003 .

6 Cole, Juan: "Shiite religious parties fill vacuum in southern Iraq”, Middle East Report, 22.04.2003 og Young, Michael: "Is Hizbollah making a new gambit in Iraq?" The Daily Star, 06.03.2004 